\title{
Characterization and Optimization of Bacteriocin from Lactobacillus plantarum Isolated from Fermented Beef (Shermout)
}

\author{
Mona E. Elyass ${ }^{1,2}$, M. T. Shigidi ${ }^{3}$, Idress Hamad Attitalla ${ }^{2 *}$, Ahmed A. Mahdi'2,4* \\ ${ }^{1}$ Commission for Biotechnology and Genetic Engineering, National Center for Research, Khartoum, Sudan \\ ${ }^{2}$ Department of Microbiology, Faculty of Science, Omar Mukhtar University, El Beida, Libya \\ ${ }^{3}$ Department of Microbiology, Faculty of Veterinary Science, University of Khartoum, Khartoum, Sudan \\ ${ }^{4}$ Department of Agricultural Biotechnology, Faculty of Agriculture, University of Khartoum, Khartoum, Sudan \\ Email: *idressattitalla2004@yahoo.com, *mahdi.ahmed34@gmail.com
}

How to cite this paper: Elyass, M.E., Shigidi, M.T., Attitalla, I.H. and Mahdi, A.A. (2017) Characterization and Optimization of Bacteriocin from Lactobacillus plantarum Isolated from Fermented Beef (Shermout). Open Journal of Applied Sciences, 7, 83-97. https://doi.org/10.4236/ojapps.2017.73008

Received: January 27, 2017

Accepted: March 12, 2017

Published: March 15, 2017

Copyright $(0) 2017$ by authors and Scientific Research Publishing Inc. This work is licensed under the Creative Commons Attribution International License (CC BY 4.0).

http://creativecommons.org/licenses/by/4.0/

\begin{abstract}
Many lactic acid bacteria (LAB) were isolated from "Shermout", a popular Sudanese fermented beef product intended for long storage. An isolate that demonstrated significant antibacterial activity was identified as Lactobacillus plantarum PM4 based on phenotypic, physiological and biochemical characteristics and carbohydrate utilization patterns. The inhibitory activity of the partially purified bacteriocin was completely arrested by the proteolytic enzymes proteinase- $\mathrm{k}$ and pepsin but not by $\alpha$-amylase, asserting its proteinaceous nature. The activity was not due to $\mathrm{H}_{2} \mathrm{O}_{2}$ as similar inhibition was obtained by cell-free supernatant (CFS) produced under anaerobic conditions. The bacteriocin showed a molecular weight in the range of $3-5 \mathrm{kDa}$ and had a bactericidal mode of action. No significant reduction in activity was observed on heating to $60^{\circ} \mathrm{C}$ for $60 \mathrm{~min}$, but activity was lost on heating to $100^{\circ} \mathrm{C}$ or autoclaving. Highest inhibitory activity was at $\mathrm{pH} 5.5$ and there was appreciable reduction in activity at $\mathrm{pH} 3,7$ or 9 . There was no drop in activity at $-80^{\circ} \mathrm{C}$ or $-20^{\circ} \mathrm{C}$ up to four weeks of storage. However, at $4^{\circ} \mathrm{C}$ and $35^{\circ} \mathrm{C}$, a gradual decline in activity was observed. $L$ b. plantarum PM4 exhibited bactericidal activity against Staphylococcus aureus, Bacillus subtilis, Enterococcus faecalis, Escherichia coli ATCC25922, Klebsiella pneumoniae and Proteus vulgaris. Bacteriocin production generally coincided with the phase of maximum growth and the best combination for maximum production of inhibitory activity was at $\mathrm{pH} 5.5$ for $48 \mathrm{~h}$ whether incubated at $25^{\circ} \mathrm{C}, 30^{\circ} \mathrm{C}$ or $37^{\circ} \mathrm{C}$. Lb. plantarum $\mathrm{PM} 4$ showed promise as a starter culture in the fermentation of preserved meat products.
\end{abstract}




\section{Keywords}

Lactobacillus plantarum, Bacteriocin, Fermented Beef

\section{Introduction}

Lactic acid bacteria (LAB) is a group of Gram positive facultative anaerobic bacteria that are able to produce antagonistic molecules in their growth medium that can be used as antimicrobials and preservatives. These antagonistic properties of LAB are allied to their safe history of use in traditional fermented food products that make them very attractive as biopreservatives that can replace or allow reduction of chemical additives [1]. LAB is used in food biopreservation because they are safe for human consumption enjoying the status of GRAS (Generally Recognized as Safe) and are the prevalent indigenous microflora in many foods. Accordingly, a wide variety of LAB strains are routinely employed as starter cultures in the manufacture of meat, dairy, vegetable and bakery products [2] [3]. One of the most important contributions of these bacteria-whether indigenous or added as starters-is the extension of shelf life of the fermented products through inhibition of the growth of spoilage and pathogenic bacteria in these foods due to competition for nutrients and the presence of the antagonistic molecules such as lactic acid, hydrogen peroxide, diacetyl and bacteriocins [4]. Moreover, health benefits acclaimed to be offered by LAB include production of vitamins, immunomodulation, reduction in the risk of diarrhea, and a decrease in serum cholesterol [5] [6] [7]. Among the antagonistic molecules produced by LAB are bacteriocins [8] which are antimicrobial peptides or proteins produced by strains of diverse bacterial species. The antimicrobial activity of this group of natural substances against foodborne pathogens, as well as spoilage bacteria, has raised considerable interest for their application in food preservation [2] [9] [10] [11].

Within $\mathrm{LAB}$, the lactobacilli are an important group recognized for their fermentative ability as well as health and nutritional benefits [12]. In this group, Lactobacillus plantarum is one of the most widely distributed in nature, and is one of the most versatile species, used both as starter and probiotic [13] [14]. Lb. plantarum has been isolated from various habitats, and bacteriocins have been described for strains from fermented meat products [15] [16] [17]. It is one of the most important LAB strains used for the production of fermented meat products [18]. Over the past few decades, there has been an increasing research interest in the development of nitrite-free meat curing systems. The principle concern with the use of nitrite for curing of meat is the eventual formation of carcinogenic $\mathrm{N}$-nitrosamines [19]. Consumers are increasingly demanding food that is free from pathogens, with minimal processing and fewer chemical preservatives and additives. Thus biopreservation has gained increasing attention as means of naturally controlling the shelf life and safety of meat products. In recent years bacteriocins of lactic acid bacteria have attracted the attention of 
many investigators because of their use as a natural food preservative with probiotic capability within the human body after ingestion of food [14] [20].

Shermout is sun-dried lean beef strips widely used for prolonged storage. It has unique sensory characteristics and is very popular in Sudan and neighboring countries. It is very similar to "kaddid" [17] and jerky [21] [22] except that no or little salt is added and the product undergoes mild fermentation by indigenous microbial flora, mainly LAB. The process is artisanal in nature, with no bacterial starters added and is usually subject to microbial deterioration. Various gram positive and gram negative bacteria like Salmonella typhi, Bacillus subtilis and staphylococci are the main causative organisms [23]. The objectives of this study were the isolation and identification of $L b$. plantarum from local Sudanese fermented beef (shermout), characterization of the bacteriocin it produces and determination of its antibacterial activity, study of the bacteriocin kinetics and determination of the optimum growth conditions for bacteriocin production.

\section{Materials and Methods}

\subsection{Isolation of the Bacteriocinogenic Bacterium}

Ten $g$ of traditional Sudanese fermented beef (shermout) samples were aseptically added to $90 \mathrm{~mL}$ sterile peptone water ( $10 \mathrm{~g}$ peptone/L distilled $\mathrm{H}_{2} \mathrm{O}$ ), carefully shaken and were left to homogenize for I h. Serial decimal dilutions were prepared from the sample homogenate, and were streaked onto duplicate plates of MRS medium [24] to which $0.1 \%(\mathrm{w} / \mathrm{v})$ nystatin had been added to inhibit fungal growth [25]. The streaked plates were incubated anaerobically at $30^{\circ} \mathrm{C}$ for 2 - 3 days in an anaerobic jar system (GasPak; BBL Microbiology Systems, Cockeysville, Maryland, USA) with a gas-generating kit (BR0038B, Oxoid, Hampshire, UK). The pure colonies obtained were examined for Gram reaction, catalase activity, and spore formation. A Gram-positive, catalase-negative, nonspore-forming rod was selected and identified as Lactobacillus plantarum by use of the fermentation pattern from KB009 HiCarbohydrate identification kit (HiMedia Laboratories, Mumbai, India) in conjunction with other tests which included growth at 10 and $45 \mathrm{C}$, tolerance of $6.5 \% \mathrm{NaCl}, \mathrm{pH}(4.4$ and 9.6) and gas production from glucose.

\subsection{Production, Partial Purification and Characterization of Supernatant from Lb. plantarum PM4}

For partial purification of the cell-free supernatant (CFS), a modification of the method of ten Brink et al. (1994) [26] was adopted. Sensitivity of the CFS to various enzymes (proteinase K, pepsin, $\alpha$-amylase) was conducted [27]. Production of the inhibitory factor during anaerobic growth was investigated following the technique detailed in [28]. The effects of heating $\left(40^{\circ} \mathrm{C}, 60^{\circ} \mathrm{C}, 100^{\circ} \mathrm{C}\right.$ for 10 , 30 and 60 minutes in addition to autoclaving at $121^{\circ} \mathrm{C}$ and $15 \mathrm{psi}$ ) and different $\mathrm{pH}$ values (3.0, 5.0, 7.0 and 9.0) were tested according to [29]. The stability of the antagonistic activity of the CFS during storage $\left(-80^{\circ} \mathrm{C},-20^{\circ} \mathrm{C}, 4^{\circ} \mathrm{C}\right.$ and $35^{\circ} \mathrm{C}$ for 4 weeks) was also tested. The retained activity in all tests was determined using 
the agar well diffusion test utilizing Staphylococcus aureus ATCC43306 as the indicator organism.

For molecular weight determination, the active moiety in the CFS was first precipitated by addition of $40 \%(\mathrm{w} / \mathrm{v})$ ammonium sulfate, centrifuged $(6000 \mathrm{rpm}$ for 15 minutes), and the pellet and pellicle were concentrated and used for protein separation by tricine-sodium dodecyl sulfate polyacrylamide gel electrophoresis (Tricine-SDS-PAGE) using 15\% acrylamide. The gel electrode assembly was placed in a Mini PROTEAN II electrophoresis chamber (BIORAD), and the protein was electrophoresed at 100 volts for about $2 \mathrm{~h}$. A protein molecular weight marker (MoBiTec $\mathrm{GmbH})$ with a molecular weight range of 14.0 to 116.0 KDa was included.

Staining of the gels was done by covering with Coomassie blue stain overnight and the preparation was destained with a buffer composed of $10.0 \mathrm{ml}$ glacial acetic acid, $50.0 \mathrm{ml}$ methanol and $100 \mathrm{ml}$ deionized water.

\subsection{Mode of Action}

This test was conducted to find out whether the antagonistic effect of the CFS was bactericidal or bacteriostatic in nature. The procedure followed was similar to that described in [30] and [31].

\subsection{Spectrum of Activity}

The inhibitory activity was tested against eight indicator bacteria, namely: $S$. aureus ATCC 25923, Enterococcus faecalis ATCC 10541, Escherichia coli ATCC 25922, E. coli (local isolate), Pseudomonas aeruginosa ATCC 27853, Klebsiella pneumoniae ATCC 10031, Proteus vulgaris ATCC 6380 and Salmonella typhi ATCC 1319106. The antagonistic activity was determined by the well diffusion method in Nutrient Agar plates. Diameters of the inhibition zones were measured after $24 \mathrm{~h}$ of incubation at $35^{\circ} \mathrm{C}$.

\subsection{Kinetics of Growth and Bacteriocin Production}

The kinetics of growth and production of the antagonistic activity was investigated using the procedure described by [32]. MRS broth $(250 \mathrm{~mL})$ was inoculated with $1 \%$ of an overnight culture of the strain and incubated at $30^{\circ} \mathrm{C}$ without agitation under uncontrolled $\mathrm{pH}$ conditions. Samples were removed at hourly intervals up to $13 \mathrm{~h}$, and then at 24,25 and $26 \mathrm{~h}$ from start of the investigation. Measurement of biomass by absorbance at $600 \mathrm{~nm}, \mathrm{pH}$ measurement and determination of the antibacterial activity were carried out by assaying the effect of serial two-fold dilutions of the CFS on Staphylococcus aureus ATCC 43306 by the well-diffusion method. The antimicrobial titer was expressed in arbitrary units $(\mathrm{AU} / \mathrm{mL})$. One arbitrary unit was defined as the reciprocal of the highest dilution showing a clear inhibition zone around the well [33].

\subsection{Optimization of Growth and Bacteriocin Production}

For determination of the effects of incubation temperature, $\mathrm{pH}$ of the growth 
medium and incubation period on bacteriocin production, three levels of each of these three factors were chosen and tested. The temperature levels were $25^{\circ} \mathrm{C}$, $30^{\circ} \mathrm{C}$ and $37^{\circ} \mathrm{C}$, the $\mathrm{pH}$ values were 5.0, 5.5 and 6.0 while the incubation times were 24, 48 and $72 \mathrm{~h}$. The test isolate was grown in MRS broth. Growth was measured as optical densities (O.D.) at the wavelength of $600 \mathrm{~nm}$, and inhibitory activity was measured in arbitrary units (AU).

\section{Results and Discussion}

\subsection{Isolation and Screening of the Bacteriocinogenic Bacterium}

A total of 39 isolates of antagonistic LAB were obtained from Sudanese fermented beef. All isolates were Gram-positive, catalase-negative, non-spore forming rods or cocci capable of growth under anaerobic conditions, conforming to the characteristics of lactic acid bacteria [34]. An isolate that gave positive result in the preliminary screening (spot on lawn method) against indicator bacteria (Staphylococcus aureus ATCC 43306, Bacillus subtilis NCTC 8236) with good inhibition zone diameter (well diffusion method) was selected and identified as Lactobacillus plantarum PM4. The inhibition zone by the selected isolate was produced as early as $24 \mathrm{~h}$. The isolate was rod shaped, did not grow at $10^{\circ} \mathrm{C}$ but grew at $45^{\circ} \mathrm{C}$. It grew at $\mathrm{pH} 4.4$ but not at $\mathrm{pH}$ 9.6. It did not grown in the presence of $6.5 \%$ of $\mathrm{NaCl}$, and could not hydrolyse arginine. It therefore belonged to the genus Lactobacillus (homofermentative lactobacilli) [34] [35] [36] [37]. Table 1 shows the pattern of utilization of 35 sugars by the isolate based on which it was identified as Lactobacillus plantarum PM4 [38] [39].

\subsection{Characterization of the Cell-Free Supernatant (CFS)}

The partially purified CFS from $L b$. plantarum PM4 was subjected to various treatments. Table 2 shows effects of the enzymes proteinase-k, pepsin and $\alpha$ amylase on the CFS. No inhibition was produced by the CFS in presence of the protein-digesting enzymes (proteinase-k and pepsin) indicating complete destruction of the inhibitory substance in the CFS, and asserting its proteinaceus nature; while no reduction in the inhibitory activity was observed in the presence of the carbohydrate-degrading $\alpha$-amylase. No inhibitory activity was shown in the uninoculated medium containing no enzyme (negative control). This suggested that the antibacterial activity was associated with bacteriocin [40] [41]. Treatment with a-amylase did not affect the inhibitory activity suggesting that the CFS, similar to most other bacteriocins, was not glycosylated [38] [39] [42] [43].

As production of hydrogen peroxide under aerobic conditions is one of the potent defense weapons of LAB, elimination of this factor was achieved through growing the isolate under anaerobic conditions. There was no difference in inhibitory activity against indicator bacterium whether $L$ b. plantarum PM4 was grown under aerobic or anaerobic conditions (result not shown), indicating that the inhibitory activity was not due the production of $\mathrm{H}_{2} \mathrm{O}_{2}$. Figure 1 shows that the widest inhibition zone of the CFS from Lb. plantarum PM4 on Staph. aureus 
ATCC 43306 (20 mm) occurred at pH 5.0, declining gradually with either increase or decrease in $\mathrm{pH}$ value.

No reduction was observed in the inhibitory activity of the CFS on heating to $40^{\circ} \mathrm{C}$ for 10 or $30 \mathrm{~min}$, but a slight reduction was observed when the heating was continued for 60 minutes. However, a 7.7\% reduction in activity was observed on heating at $60^{\circ} \mathrm{C}$, whether for 10,30 or 60 minutes, while heating to $100^{\circ} \mathrm{C}$ or $121^{\circ} \mathrm{C}$ resulted in complete loss of the activity regardless of the length of the heating period (Figure 2). Loss of activity after heat treatment at $121^{\circ} \mathrm{C}$ for 15 min has been reported [44].

Table 1. Carbohydrate utilization pattern by Lb. plantarum M4.

\begin{tabular}{|c|c|c|c|}
\hline Carbohydrates & Utilization & Carbohydrates & Utilization \\
\hline Lactose & + & Glucosamine & + \\
\hline Xylose & - & Dulcitol & + \\
\hline Maltose & + & Inositol & + \\
\hline Fructose & + & Sorbitol & + \\
\hline Dextrose & + & Mannitol & + \\
\hline Galactose & + & Adonitol & - \\
\hline Raffinose & + & a-Methyl-D-glucoside & + \\
\hline Trehalose & + & Ribose & + \\
\hline Melibiose & + & Rhamnose & - \\
\hline Sucrose & + & Cellobiose & + \\
\hline L-Arabinose & + & Melezitose & + \\
\hline Malonate utilization & + & a-Methyl-D-mannoside & + \\
\hline Mannose & + & Xylitol & + \\
\hline Inulin & + & ONPG & - \\
\hline Sodium Gluconate & + & Esculin hydrolysis & - \\
\hline Glycerol & + & D-Arabinose & + \\
\hline Salicin & + & Citrate utilization & + \\
\hline Sorbose & + & & \\
\hline
\end{tabular}

$+=$ utilized; $-=$ not utilized.

Table 2. Effect of enzymes on activity of the CFS from Lb. plantarum M4 against Staph. aureus ATCC 43306 (Inhibition zone diameters in $\mathrm{mm}$ ).

\begin{tabular}{cc}
\hline Enzymes & Inhibition zone diameter $(\mathrm{mm})$ \\
\hline Proteinase-K & 0.0 \\
Pepsin & 0.0 \\
$\alpha$-amylase & 14 \\
uninoculated medium with no enzyme & 0.0 \\
Enzyme-free cell supernatants & 14 \\
\hline
\end{tabular}




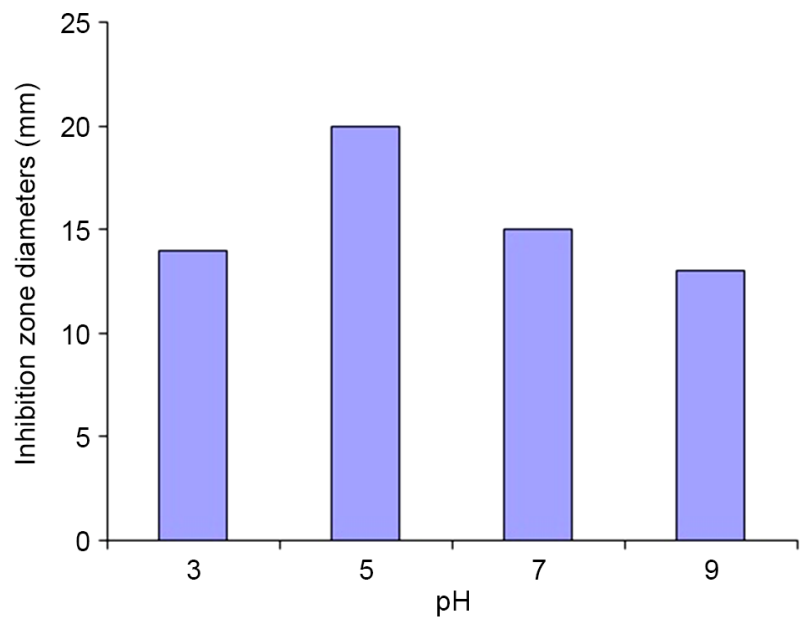

Figure 1. Effect of $\mathrm{pH}$ on inhibitory activity of CFS from Lb. plantarum M4 on Staph. aureus ATCC43306.

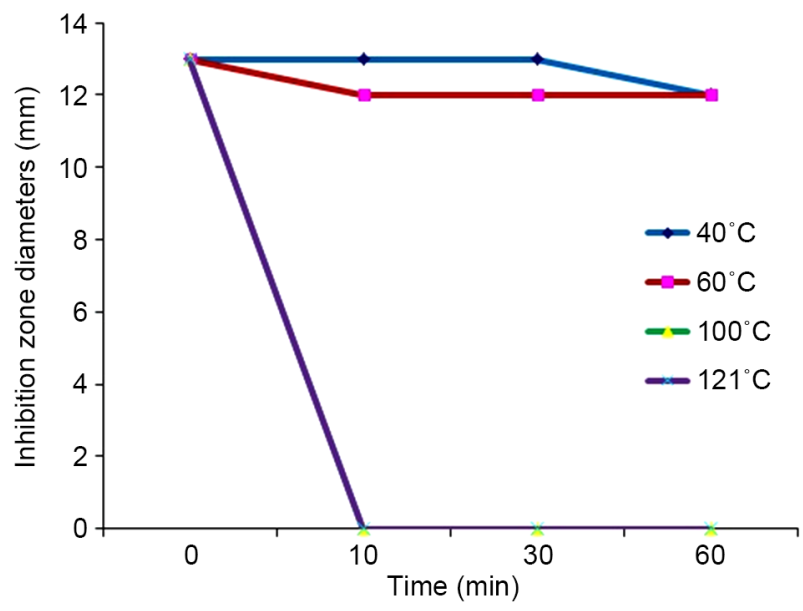

Figure 2. Effect of heating on activity of CFS from $L b$. plantarum M4.

No drop in activity of the CFS was observed on storage at $-80^{\circ} \mathrm{C}$ or $-20^{\circ} \mathrm{C}$ up to four weeks. However, at $4^{\circ} \mathrm{C}$ and $35^{\circ} \mathrm{C}$ a gradual decline in activity was observed starting from the second week, and by the fourth week, the retained activities were $78.6 \%$ and $77 \%$ of the starting activities at $4{ }^{\circ} \mathrm{C}$ and $35^{\circ} \mathrm{C}$, respectively (Figure 3). Bacteriocins produced by $L$. plantarum F1 remained fully stable after storage for 60 days at $-20^{\circ} \mathrm{C}$, but declined or became undetectable after storage for 80 to 120 days at $37^{\circ} \mathrm{C}$, indicating that cold temperature may be the most appropriate preservation technique [45].

Figure 4 shows bands produced by the electrophoretic separation of the protein in the Lb. plantarum PM4 CFS in comparison to a marker of standard protein molecular weights. The molecular weight of the protein was in the range of $3-4 \mathrm{KDa}$. This is the same as bacteriocin ST414BZ (3.7 kDa) from $L$ b. plantarum ST414BZ [46], plantaricin $35 \mathrm{~d}(4.5 \mathrm{kDa})$ produced by Lb. plantarum $35 \mathrm{~d}$ [47], bacteriocins ST28MS and ST26MS with 5.5 and $2.8 \mathrm{kDa}$, respectively [48] and bacteriocin BM-1 of $4638.142 \mathrm{Da}$ [49]. This is within the range of most bacteriocins reported for the genus Lactobacillus [40]. 


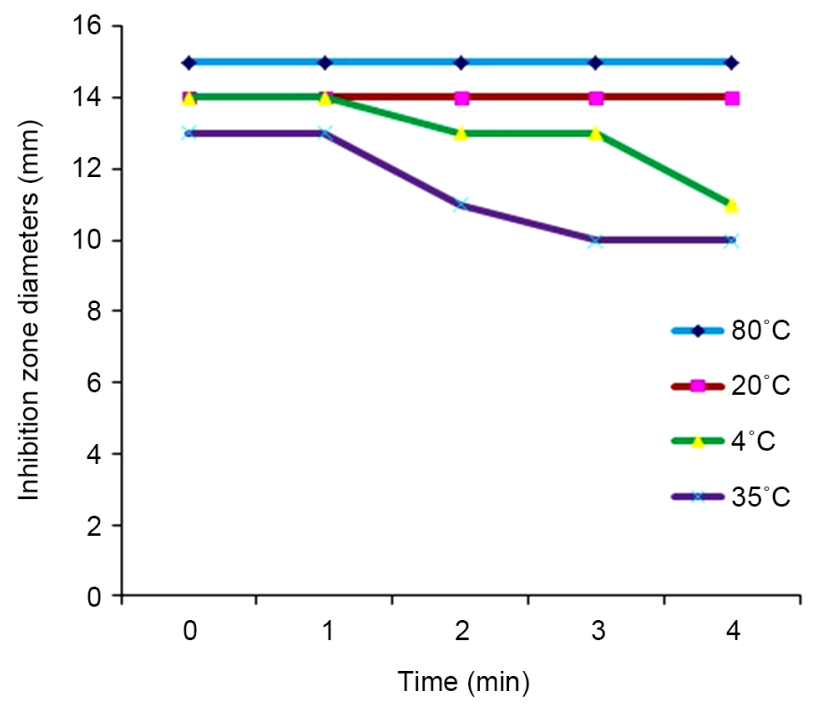

Figure 3. Effect of storage at $-80^{\circ} \mathrm{C},-20^{\circ} \mathrm{C}, 4^{\circ} \mathrm{C}$ and $35^{\circ} \mathrm{C}$ for four weeks on activity of CFS from $L b$. plantarum M4.

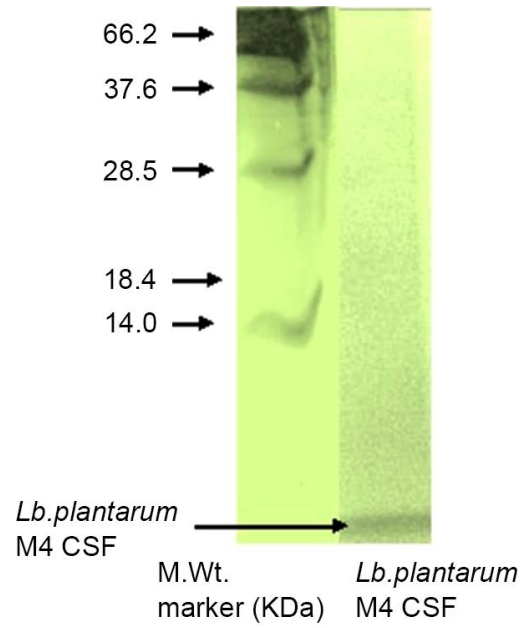

Figure 4. Gel electrophoresis (SDS-PAGE) of the inhibitory moiety of Lb. plantarum M4 stained with Coomassie blue.

\subsection{Mode of Action}

On addition of the CFS from Lb. plantarum PM4 to Staphylococcus aureus ATCC 43306, growth was completely arrested, with no increase in the optical density of the treated broth culture up to five hours from the time of addition, while the optical density of the untreated broth culture rose from 0.1 to 0.39 during those five hours (Figure 5). No growth was obtained on re-culturing the treated broth culture on fresh Nutrient Agar medium indicating that it has a bactericide effect on $S$. aureus. This is similar to the bacteriocidal mode of activity of bacteriocin AMA-K from $L$ b. plantarum AMA-K [50] and plantaricin 35d produced by $L b$. plantarum 35d [47].

\subsection{Spectrum of Activity}

Table 3 depicts the spectrum of activity of the CFS against eight bacterial strains. 


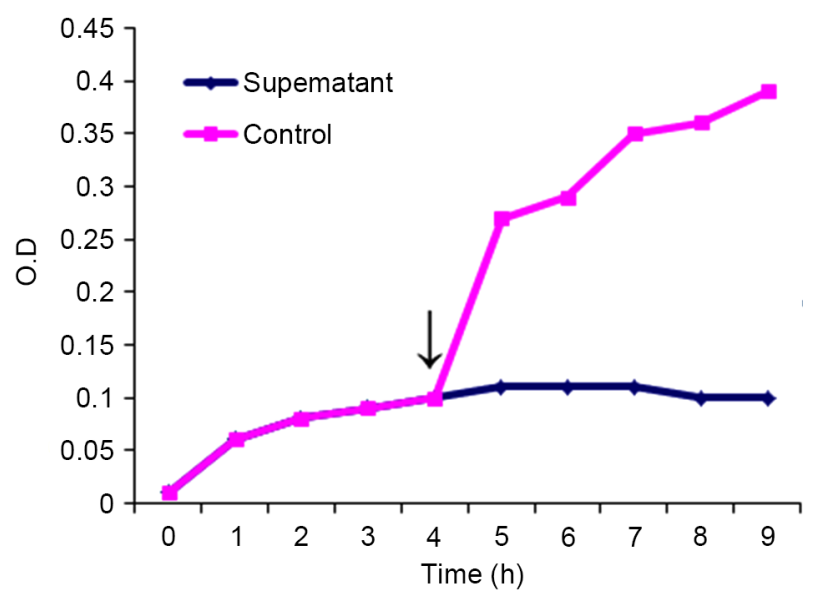

Figure 5. Mode action of CFS from $L b$. plantarum M4. Arrow indicates time of addition of CFS.

Table 3. Spectrum of inhibitory activity of CFS from $L b$. plantarum M4 against eight target organisms (zone diameters, $\mathrm{mm}$ ).

\begin{tabular}{cc}
\hline Target organism & Inhibition zone diameter $(\mathrm{mm})$ \\
\hline Enterococcus faecalis ATCC 10541 & 12 \\
Staph. aureus ATCC 25923 & 12 \\
Klebsiella pneumoniae ATCC 10031 & 9 \\
Proteus vulgaris ATCC 6380 & 11 \\
Salmonella typhi ATCC 1319106 & 0 \\
E. coli ATCC 25922 & 10 \\
E. coli (local isolate) & 0 \\
Pseudomonas aeruginosa ATCC 27853 & 0 \\
\hline
\end{tabular}

It was active against both Gram-positive and Gram-negative bacteria. This spectrum of activity is similar to that reported for other plantaricins. For instance, it was reported that the bacteriocin produced by $L b$. plantarum was effective against both gram positive and gram negative bacteria [51]. Also bacteriocin C8 from $L b$. plantarum was reported to have inhibitory activity against not only many Gram-positive but also Gram-negative bacteria such as Escherichia coli [39]. Lb. plantarum BM-1 isolated from a traditionally fermented Chinese meat was found to produce a novel bacteriocin that is active against a wide range of gram-positive and gram-negative bacteria [49].

\subsection{Kinetics of Growth and Bacteriocin Production}

Bacteriocin production (measured as inhibitory activity (AU)) by Lb. plantarum PM4 generally coincided with the phase of maximum growth (Figure 6). The acivity was detected after just $5 \mathrm{~h}$ indicating that the bacteriocin is a primary metabolite. However, maximum activity was obtained between 10 and $26 \mathrm{~h}$ and maximal growth occurred at the $25 \mathrm{~h}$ from inoculation. Similarly, it was reported 


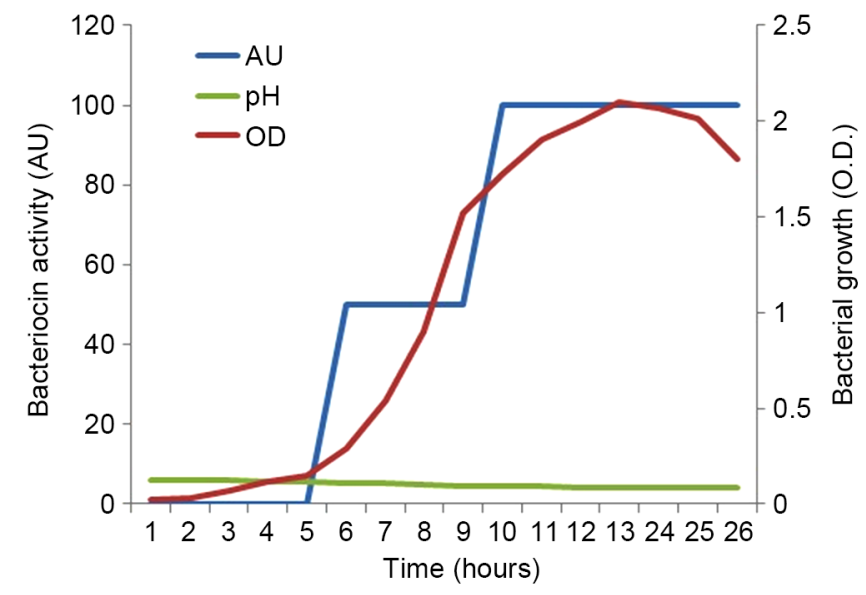

Figure 6. Kinetics of growth and bacteriocin production by Lb. plantarum M4.

[48] that two bacteriocins from Lb. plantarum (ST28MS and ST26MS) showed detectable levels of inhibitory activity after $5 \mathrm{~h}$ suggesting that the peptide is a primary metabolite. Similar results were also reported for plantaricin Y [52] and bacteriocin ST13BR [53]. Both maximum growth and inhibitory activity were obtained at $\mathrm{pH} 4.4-4.2$. Bacteriocin production is usually observed to be proportional to growth [54] [55].

\subsection{Optimization of Bacteriocin Production}

Optimization of bacteriocin production by $L b$. plantarum PM4 was studied in MRS broth using temperature, $\mathrm{pH}$ and length of incubation period (time) as variables. At $\mathrm{pH} 5.0$, production of the inhibitory activity in the CFS was low (around $50 \mathrm{AU} / \mathrm{mL}$ ) whether the $\mathrm{CFS}$ was incubated at $25^{\circ} \mathrm{C}$ or $30^{\circ} \mathrm{C}$ for up to $72 \mathrm{~h}$. However, at $37^{\circ} \mathrm{C}$, production surged to $100 \mathrm{AU} / \mathrm{mL}$ at the first $24 \mathrm{~h}$ but then declined to around $50 \mathrm{AU} / \mathrm{mL}$ (Figure $7(\mathrm{a})$ ). Production at $\mathrm{pH} 5.5$ was generally higher than at $\mathrm{pH} 5.0$, being around $100 \mathrm{AU} / \mathrm{mL}$ at the first $24 \mathrm{~h}$, and the surging to $200 \mathrm{AU} / \mathrm{mL}$ at $48 \mathrm{~h}$, then receding (Figure 7(b)). At pH 6.0, incubation at $25^{\circ} \mathrm{C}$ for $48 \mathrm{~h}$ resulted in $100 \mathrm{AU} / \mathrm{mL}$ while all other incubation conditions resulted in lower yield (Figure $7(\mathrm{c})$ ). Accordingly, the best combination of incubation conditions for production of the inhibitory activity by Lb. plantarum $\mathrm{M} 4$ appears to be at $\mathrm{pH} 5.5$ for $48 \mathrm{~h}$ whether incubated at $25^{\circ} \mathrm{C}, 30^{\circ} \mathrm{C}$ or $37^{\circ} \mathrm{C}$.

Maximum production of bacteriocin ST13BR by $L$ b. plantarum ST13BR was recorded at $30^{\circ} \mathrm{C}$ and not at $37^{\circ} \mathrm{C}$ [53]. However, optimum production of bacteriocin by $L b$. plantarum $\mathrm{F} 12$ was reported at $37^{\circ} \mathrm{C}$ [56]. Optimal bacteriocin production $(12,800 \mathrm{AU} / \mathrm{mL})$ from $L b$. plantarum AMA-K was recorded in MRS broth with an initial $\mathrm{pH}$ of 6.0 and 5.5 [50]. Also, maximum activity of bacteriocin ST26MS was recorded in MRS broth with an initial pH of 5.5 [48]. It should be noted that the titers reported for CFS are usually thousands of times lower than those reported for purified bacteriocins [57]. The use of bacteria isolated from meat may contribute to a better sensory quality of the meat fermented products [58]. 
(a)

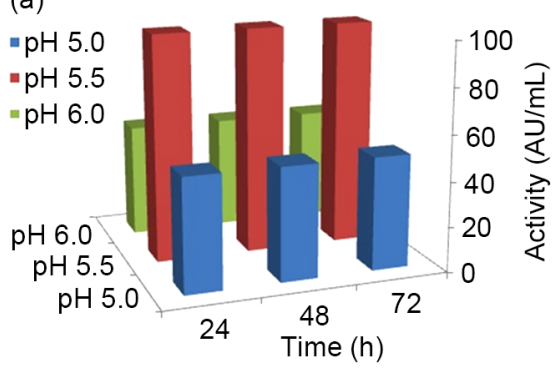

(b)

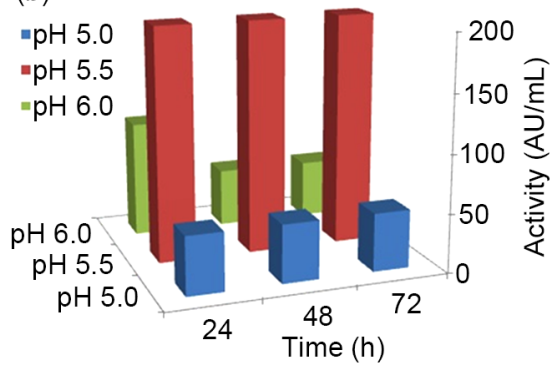

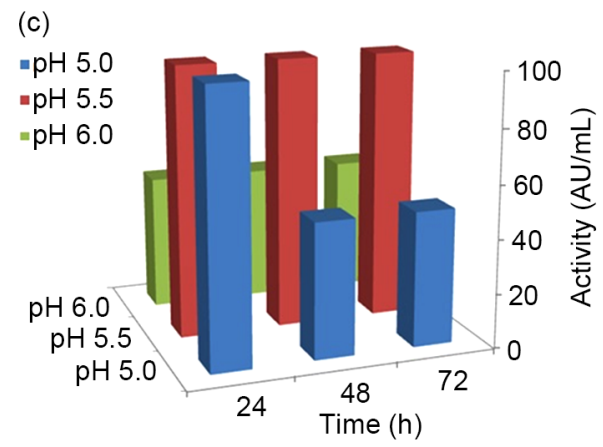

Figure 7. Activity of CFS from $\mathrm{Lb}$. plantarum $\mathrm{M} 4$ as affected by $\mathrm{pH}$ and incubation period at (a) $25^{\circ} \mathrm{C}$, (b) $30^{\circ} \mathrm{C}$ and (c) $37^{\circ} \mathrm{C}$.

\section{Conclusion}

Results of this study indicated that $L b$. plantarum PM4 isolated from fermented beef (shermout) exhibited promising antimicrobial activity against both Gram positive and Gram negative bacteria, and could be used as a starter culture in the processing of fermented meat as well as biopreservative. Acidification carried out by LAB such as $L b$. plantarum and the production of bacteriocins contribute, in addition to good manufacturing practices, to the inhibition of food pathogens such as Salmonella, E. coli and $S$. aureus and can ensure safe and improved product quality.

\section{Conflict of Interests}

The authors declare no conflict of interests whatsoever.

\section{References}

[1] Arena, M.P., Silvain, A., Normanno, G., Grieco, F., Drider, D., Spano, G. and Fiocco, D. (2016) Use of Lactobacillus plantarum Strains as Bio-Control Strategy against Food-Borne Pathogenic Microorganisms. Frontiers in Microbiology, 7, 464-474. https://doi.org/10.3389/fmicb.2016.00464

[2] Noopur, M.S., Sucheta, N.P. and Aglave, B.A. (2010) Extraction of Bacteriocin and Study of Its Antagonistic Assay. International Journal of Biotechnology and Biochemistry, 6, 865-870.

[3] Hassanzadazar, H. and Ehsani, A. (2013) Phenotypic Characterization of Lactic Acid Bacteria Isolated from Traditional Koopeh Cheese. Global Veterinaria, 10, 148-152.

[4] Noordiana, N., Fatimah, A.B. and Mun, A.S. (2013) Antibacterial Agents Produced 
by Lactic Acid Bacteria Isolated from Threadfin Salmon and Grass Shrimp. International Food Research Journal, 20, 117-124.

[5] Briand, V.R., Buffet, P., Genty, S., Lacombe, K., Godineau, N., Salomon, J. and Bouchaud, O. (2006) Absence of Efficacy of Nonviable Lactobacillus acidophilus for the Prevention of Traveler's Diarrhea: A Randomized, Double-Blind, Controlled Study. Clinical Infectious Diseases, 43, 1170-1175. https://doi.org/10.1086/508178

[6] Myllyluoma, E., Ahlroos, T., Veijola, L. and Rautelin, H. (2007) Effects of anti-Helicobacter pylori Treatment and Probiotic Supplementation on Intestinal Microbiota. International Journal of Antimicrobial Agents, 29, 66-72. https://doi.org/10.1016/j.ijantimicag.2006.08.034

[7] Linsalata, M., Cavallini, A., Messa, C., Orlando, A. and Russo, F. (2010) Lactobacillus rhamnosus GG Influences Polyamine Metabolism in HGC-27 Gastric Cancer Cell Line: A Strategy toward Nutritional Approach to Chemoprevention of Gastric Cancer. Current Pharmaceutical Design, 16, 847-853. https://doi.org/10.2174/138161210790883598

[8] Nishie, M., Nagao, J. and Sonomoto, K. (2012) Antibacterial Peptides "Bacteriocins": An Overview of Their Diverse Characteristics and Applications. Biocontrol Science, 17, 1-16. https://doi.org/10.4265/bio.17.1

[9] Gong, H.S., Meng, X.C. and Wang, H. (2010) Plantaricin MG Active against Gram-Negative Bacteria Produced by Lactobacillus plantarum KLDS1.0391 Isolated from "Jiaoke", a Traditional Fermented Cream from China. Food Control, 21, 8996. https://doi.org/10.1016/j.foodcont.2009.04.005

[10] Ana, A.Z. (2012) Antimicrobial Activities of Lactic Acid Bacteria Strains Isolated from Nile Tilapia Intestine (Oreochromis niloticus). Journal of Biology and Life Science, 4, 164-171.

[11] Elyass, M.E., Altayar, M.A., Mahdi, A.A., Abdelrawaf, S.A., Shigidi, M.T. and Attitalla, I.H. (2015) Characterization and Evaluation of Antimicrobial Activity of Bacteriocins from Lactobacillus curvatus and Pediococcus pentosaceus. Journal of Microbial Pathophysiology \& Pathogenesis, 1, 1-7.

[12] Kannahi, M. and Viji, N. (2014) Isolation and Characterization of Bacteriocin Producing Lactobacilli from Dairy Butter Sample. International Journal of Pharmaceutical Sciences Review and Research, 29, 183-186.

[13] Da Silva Sabo, S., Vitolo, M., Gonzalez, J.M.D. and de Souza Oliveira, R.P. (2014) Overview of Lactobacillus plantarum as a Promising Bacteriocin Producer among Lactic Acid Bacteria. Food Research International, 64, 527-536. https://doi.org/10.1016/j.foodres.2014.07.041

[14] Guidone, A., Zotta, T., Ross, R.P., Stanton, C., Rea, C.R., Parente, E. and Rocciardi, A. (2014) Functional Properties of $L b$. plantarum Strains: A Multivariate Screening Study. LWT-Food Science and Technology, 56, 69-76. https://doi.org/10.1016/j.lwt.2013.10.036

[15] Garriga, M., Hugas, M., Aymerich, T. and Monfort, J. (1993) Bacteriocinogenic Activity of Lactobacilli from Fermented Sausages. Journal of Applied Bacteriology, 75, 142-148. https://doi.org/10.1111/j.1365-2672.1993.tb02759.x

[16] Gençcelep, H., Kaban, G. and Kaya, M. (2007) Effect of Starter Cultures and Nitrite Levels on Formation of Biogenic Amines in Sucuk. Meat Science, 77, 424-430. https://doi.org/10.1016/j.meatsci.2007.04.018

[17] Mahdjoub Bessam, H., Missouri, M. and Kridech, S. (2016) Bacterial Ecology of the "Kaddid", Typical Dried Meat of the North Africa, during Its Traditional Fermentation. Journal of Food and Nutrition Sciences, 4, 70-77.

https://doi.org/10.11648/j.jfns.20160403.15 
[18] Ritz Barba, J.L., Piard, J.C. and Jimenez-Diaz, R. (1991) Plasmid Profile and Curing of Plasmids in Lactobacillus plantarum Strains Isolated from Green Olive Fermentation. Journal of Applied Bacteriology, 71, 417-421. https://doi.org/10.1111/j.1365-2672.1991.tb03810.x

[19] Parente, E., Martuscelli, M., Gardini, F., Grieco, S., Crudele, M.A. and Suzzi, G. (2001) Evolution of Microbial Populations and Biogenic Amine Production in Dry Sausages Produced in Southern Italy. Journal of Applied Microbiology, 90, 882-891. https://doi.org/10.1046/j.1365-2672.2001.01322.x

[20] Enan, G., El-Didamsuny, G., El-Helali, M. and Zakaria, A.R. (2014) Antimicrobial Activity of Enterococcus faecium NM2: Purification, Characterization and Bactericidal Action of Enterocin NM2. Asian Journal of Applied Science, 7, 66-78. https://doi.org/10.3923/ajaps.2014.66.78

[21] Campbell-Platt, G. (1987) Fermented Foods of the World: A Dictionary and Guide. Butterworths, London.

[22] Campbell-Platt, G. and Cook, P.E. (1995) Fermented Meats. Blackie Academic and Professional, London. https://doi.org/10.1007/978-1-4615-2163-1

[23] Dirar, H.A. (1993) The Indigenous Fermented Foods of the Sudan: A Study in African Food and Nutrition. Cambridge University Press, Cambridge.

[24] De Man, J.C., Rogosa, M. and Sharpe, M.E. (1960) A Medium for the Cultivation of Lactobacilli. Journal of Applied Bacteriology, 23, 130-135.

https://doi.org/10.1111/j.1365-2672.1960.tb00188.x

[25] Bowman, J.P. (2005) Order VII: Methylococcales. In: Brenner, D.J., Krieg, N.R., Staley, J.T. and Garrity, G.M., Eds., Bergy's Manual of Systematic Bacteriology, 2nd Edition, Elsevier Publishing, Amsterdam, 248-269. https://doi.org/10.1007/0-387-28022-7_7

[26] Ten Brink, B., Minekus, M., van der Vossen, J.M.B.M., Leer, R.J. and Huis in't Veld, J.H.J. (1994) Antimicrobial Activity of Lactobacilli: Preliminary Characterization and Optimization of Production of Acidocin B, a Novel Bacteriocin Produced by Lactobacillus acidophilus M46. Journal of Applied Bacteriology, 77, 140-148. https://doi.org/10.1111/j.1365-2672.1994.tb03057.x

[27] Barefoot, S.F. and Klaenhammer, T.R. (1983) Detection and Activity of Lactacin B, a Bacteriocin Produced by Lactobacillus acidophilus. Applied and Environmental Microbiology, 45, I8-15.

[28] Lewus, C.B. and Montville, T.J. (1991) Detection of Bacteriocins Produced by Lactic Acid Bacteria. Journal of Microbiology Methods, 13, 145-150. https://doi.org/10.1016/0167-7012(91)90014-H

[29] Ivanova, I., Miteva, V., Stefanova, T., Pantev, A., Budakov, I., Danova, S., Moncheva P., Nikolova, I., Dousset, X. and Boyaval, P. (1998) Characterization of a Bacteriocin Produced by Streptococcus thermophilus 81. International Journal of Food Microbiology, 42, 147-158. https://doi.org/10.1016/S0168-1605(98)00067-1

[30] Faye, T., Langsrud, T., Nes, I.F. and Holo, H. (2000) Biochemical and Genetic Characterization of Propionicin T1, a New Bacteriocin from Propionibacterium thoenii. Applied and Environmental Microbiology, 66, 4230-4236.

https://doi.org/10.1128/AEM.66.10.4230-4236.2000

[31] Nilsen, T., Nes, I.F. and Holo, H. (2003) Enterolysin A, a Cell Wall-Degrading Bacteriocin from Enterococcus faecalis LMG 333. Applied and Environmental Microbiology, 69, 2975-2984. https://doi.org/10.1128/AEM.69.5.2975-2984.2003

[32] Ghrairi, T., Frere, J., Berjeaud, J.M. and Manai, M. (2008) Purification and Characterisation of Bacteriocins Produced by Enterococcus faecium from Tunisian Rigouta Cheese. Food Control, 19, 162-169. https://doi.org/10.1016/j.foodcont.2007.03.003 
[33] Van Reenen, C.A., Dicks, L.M.T. and Chikindas, M.L. (1998) Isolation, Purification and Partial Characterization of Plantaricin 423, a Bacteriocin Produced by Lactobacillus plantarum. Journal of Applied Microbiology, 84, 1131-1137. https://doi.org/10.1046/j.1365-2672.1998.00451.x

[34] Axelsson, L. (2004) Lactic Acid Bacteria: Classification and Physiology. In: Salminen, S., Wright, A.V. and Ouwehand, A., Eds., Lactic Acid Bacteria: Microbiological and Functional Aspects, 3rd Edition, Marcel Dekker, New York, 1-67. https://doi.org/10.1201/9780824752033.ch1

[35] Schillinger, U. and Lüke, F.K. (1987) Identification of Lactobacilli from Meat and Meat Products. Food Microbiology, 4, 199-208. https://doi.org/10.1016/0740-0020(87)90002-5

[36] Wood, B.J.B. and Holzapfel, W.H. (1995) The Genera of Lactic Acid Bacteria. Blackie Academic and Professional, London. https://doi.org/10.1007/978-1-4615-5817-0

[37] Stiles, M.E. and Holzapfel, W.H. (1997) Lactic Acid Bacteria of Foods and Their Current Taxonomy. International Journal of Food Microbiology, 36, 1-29. https://doi.org/10.1016/S0168-1605(96)01233-0

[38] Karthikeyan, V. and Santosh, S.W. (2009) Isolation and Partial Characterization of Bacteriocin Produced from Lactobacillus plantarum. African Journal of Microbiology Research, 3, 233-239.

[39] Zhou, F., Zhao, H., Bai, F., Piotr, D., Liu, Y. and Zhang, B. (2014) Purification and Characterisation of the Bacteriocin Produced by Lactobacillus plantarum Isolated from Chinese Pickle. Czech Journal of Food Sciences, 32, 430-436.

[40] De Vuyst, L. and Vandamme, E.J. (1994) Lactic Acid Bacteria and Bacteriocins: Their Practical Importance. In: de Vuyst, L. and Vandamme, E.J., Eds., Bacteriocins of Lactic Acid Bacteria: Microbiology, Genetics and Applications, Blackie Academic and Professional, London, 1-11. https://doi.org/10.1007/978-1-4615-2668-1_1

[41] Cintas, L.M., Cassaus, P., Herranz, C., Havarstein, L.S., Holo, H., Hernande, P. and Nes, I.F. (2000) Biochemical and Genetic Evidence That Enterococcus faecium L50 Produces Enterocins L50A and L50B, the Sec-Dependent Enterocin P, and a Novel Bacteriocin Secreted without an N-Terminal Extension Termed Enterocin Q. Journal of Bacteriology, 182, 6806-6814. https://doi.org/10.1128/JB.182.23.6806-6814.2000

[42] Todorov, S.D., Prévost, H., Lebois, M., Dousset, X., LeBlanc, J.G. and Franco, B.D.G.M. (2011) Bacteriocinogenic Lactobacillus plantarum ST16Pa Isolated from Papaya (Carica papaya)_From Isolation to Application: Characterization of a Bacteriocin. Food Research International, 44, 1351-1363. https://doi.org/10.1016/j.foodres.2011.01.027

[43] Todorov, S. D., LeBlanc, J.G. and Franco, B.D.G.M. (2012) Evaluation of the Probiotic Potential and Effect of Encapsulation on Survival for Lactobacillus plantarum ST16Pa Isolated from Papaya. World Journal of Microbiology and Biotechnology, 28, 973-984. https://doi.org/10.1007/s11274-011-0895-Z

[44] Andersson, R. (1986) Inhibition of Staphylococcus aureus and Spheroplasts of Gram-Negative Bacteria by Antagonistic Compound Produced by a Strain of Lactobacillus plantarum. International Journal of Food Microbiology, 3, 149-160. https://doi.org/10.1016/0168-1605(86)90010-3

[45] Ogunbanwo, S.T., Sanni, A.I. and Onilude, A.A. (2003) Characterization of Bacteriocin Produced by Lactobacillus plantarum $\mathrm{F} 1$ and Lactobacillus brevis OG1. African Journal of Biotechnology, 2, 219-227. https://doi.org/10.5897/AJB2003.000-1045

[46] Todorov, S.D. and Dicks, L.M.T. (2010) Characterization of Bacteriocins Produced 
by Two Strains of Lactobacillus plantarum Isolated from Beloura and Chouriço, Traditional Pork Products from Portugal. Meat Science, 84, 334-343. https://doi.org/10.1016/j.meatsci.2009.08.053

[47] Messi, P., Bondi, M. and Sabia, C. (2001) Detection and Pre-Liminary Characterization of a Bacteriocin (Plantaricin 35d) Produced by a Lactobacillus plantarum Strain. International Journal of Food Microbiology, 64, 193-198. https://doi.org/10.1016/S0168-1605(00)00419-0

[48] Todorov, S.D. and Dicks, L.M.T. (2005) Lactobacillus plantarum Isolated from Molasses Produces Bacteriocins Active against Gram-Negative Bacteria. Enzyme and Microbial Technology, 36, 318-326. https://doi.org/10.1016/j.enzmictec.2004.09.009

[49] Zhang, H., Liu, L., Hao, Y., Zhong, S., Liu, H., Han, T. and Xie, Y. (2013) Isolation and Partial Characterization of a Bacteriocin Produced by Lactobacillus plantarum BM-1 Isolated from a Traditionally Fermented Chinese Meat Product. Microbiology and Immunology, 57, 746-755. https://doi.org/10.1111/1348-0421.12091

[50] Todorov, S.D. (2008) Bacteriocin Production by Lactobacillus plantarum AMA-K Isolated from Amasi, a Zimbabwean Fermented Milk Product and Study of the Adsorption of Bacteriocin AMA-K to Listeria sp. Brazilian Journal of Microbiology, 39, 178-187. https://doi.org/10.1590/S1517-83822008000100035

[51] Arunava, D., Sasidharan, S., Achuthan, T. and Sindhuja, M.E. (2014) Isolation, Characterization and Estimation of Antimicrobial Activity of Novel Bacteriocin from Lactobacillus plantarum. International Journal of Current Microbiology and Applied Sciences, 3, 227-232.

[52] Chin, H.S., Chin, J.S., Kim, J.M., Yang, R. and Yoon, S-S. (2001) Detection and Antibacterial Activity of a Bacteriocin Produced by Lactobacillus plantarum. Food Science and Biotechnology, 10, 335-341.

[53] Todorov, S.D., van Reenen, C.A. and Dicks, L.M.T. (2004) Optimization of Bacteriocin Production by Lactobacillus plantarum ST13BR, a Strain Isolated from Barley Beer. Journal of General and Applied Microbiology, 50, 149-157. https://doi.org/10.2323/jgam.50.149

[54] Moretro, T., Aassen, I.M., Storro, I. and Axelsson, L. (2000) Production of Sakacin P by Lactobacillus sakei in a Completely Defined Medium. Journal of Applied Microbiology, 88, 536-545. https://doi.org/10.1046/j.1365-2672.2000.00994.x

[55] Cald'eron-Santoyo, M., Mendonza-Garc'ia, P.G., García-Alvarado, M.A. and Escudero-Abarca, B.I. (2001) Effect of Physical Factors on the Production of Bacteriocin from Pediococcus acidilactici ITV26. Journal of Industrial Microbiology and Biotechnology, 26, 191-195. https://doi.org/10.1038/sj.jim.7000108

[56] Sifour, M., Idout, T., Ouled Haddar, H., Namous, H. and Aissaoui, S. (2012) Production and Caracterization of Bacteriocin of Lactobacillus plantarum F12 with Inhibitory Activity against Listeria monocytogenes. TOJSAT, 2, 55-61.

[57] Ouda, S.M., Debevere, J. and Enan, G. (2014) Purification and Biochemical Characterization of Plantaricin UG1: A Bacteriocin Produced by Lactobacillus plantarum UG1 Isolated from Dry Sausage. Life Science Journal, 11, 271-279.

[58] de Almeida Júnior, W.L.G., Ferrari, I.S., de Souza, J.V., Barbosa, A.L., da Costa, M.M., Menezes, D.F. and Dias, F.S. (2015) Principal Criteria for Selection of Lactic Acid Bacteria for Potential Use as Probiotic in Foods. African Journal of Microbiology Research, 9, 671-686. https://doi.org/10.5897/AJMR2014.7226 
Submit or recommend next manuscript to SCIRP and we will provide best service for you:

Accepting pre-submission inquiries through Email, Facebook, LinkedIn, Twitter, etc. A wide selection of journals (inclusive of 9 subjects, more than 200 journals)

Providing 24-hour high-quality service

User-friendly online submission system

Fair and swift peer-review system

Efficient typesetting and proofreading procedure

Display of the result of downloads and visits, as well as the number of cited articles Maximum dissemination of your research work

Submit your manuscript at: http://papersubmission.scirp.org/

Or contact ojapps@scirp.org 